\title{
Impacts of anthropogenic pressures on the contemporary biogeography of threatened crocodilians in Indonesia
}

\author{
Kyle J. Shaney, Amir Hamidy, Matthew Walsh, Evy Arida \\ Aisyah Arimbi and ERIC N. SMith
}

\begin{abstract}
The Greater Sunda region of South-east Asia supports a rich diversity of economically and ecologically important species. However, human pressures are reshaping contemporary biogeography across the region. Megafaunal distributional patterns have been particularly affected because of deforestation, poaching and human-wildlife conflict. Crocodilians are at the centre of these conflicts in Indonesia and yet remain poorly studied across much of the archipelago. We conducted population surveys of saltwater crocodiles Crocodylus porosus and false gharials Tomistoma schlegelii in Sumatra, and examined whether crocodile abundance and distribution are correlated with variations in human disturbance, fishing pressure, and habitat type. We then used these data to model remaining suitable habitat for T. schlegelii across South-east Asia. We found that abundance of T. schlegelii and C. porosus was correlated with distance from human settlements, and fishtrapping pressure. We recorded the presence of $T$. schlegelii in a river system in which it was previously unknown, thus expanding the known range of the species. We also found that the predicted remaining suitable habitat for T. schlegelii in Indonesia is largely limited to areas of low human activity. From these empirical and modelling approaches we propose several key conservation priorities: (1) eliminate the use of fish traps in remaining patches of $T$. schlegelii habitat, (2) prioritize crocodile population surveys in remaining suitable habitat, particularly in remote areas, (3) consider $T$. schlegelii to be potentially Endangered locally in Sumatra, and (4) expand existing reserves around the Lower Kampar River and Berbak National Park/Sembilang National Park areas of Sumatra.
\end{abstract}

Keywords Endangered, false gharial, fish trapping, refugial, remote, reserve, Sumatra

Kyle J. Shaney (Corresponding author), Matthew Walsh and Eric N. Smith The Amphibian and Reptile Diversity Research Center and Department of Biology, University of Texas at Arlington, 501 S. Nedderman Drive, Arlington, TX 76010, USA. E-mail kjshaney@uta.edu

AMIR HaMidy and Evy ARIDA Laboratory of Herpetology, Museum Zoologicum Bogoriense, Research Center for Biology, Indonesian Institute of Sciences, Bogor, West Java, Indonesia

AisYah Arimbi Wildlife Conservation Society, Indonesia

Received 22 December 2016. Revision requested 9 March 2017.

Accepted 2 June 2017. First published online 10 November 2017.

\section{Introduction}

gricultural practices across the Greater Sunda region A (i.e. Borneo, Java, Peninsular Malaysia and Sumatra) are driving one of the world's highest rates of deforestation (Sodhi et al., 2004). Indonesia is at the forefront of contemporary global change in which habitat alteration and hunting pressure are reshaping species' distributions. In turn, vertebrate populations are increasingly being forced into remote, refugial habitat. Conversion of forest to oil palm, rubber, tea and coffee plantations, in conjunction with a lack of wildlife management resources (e.g. revenue and staff), has led to unregulated overharvesting of natural resources (Margono et al., 2012; Miettinen et al., 2014). Unregulated hunting pressure for meat, skin and the pet trade in Indonesia has also affected vertebrate populations across the Greater Sunda region (Brooks et al., 1997; Brodie et al., 2015). Although the impacts of human pressures on vertebrates in the region have been addressed to some extent, impacts on reptilian groups are largely unquantified.

Indonesia's crocodilians are an excellent model system for understanding the impacts of human pressures on contemporary biogeography. Furthermore, in light of humancarnivore conflicts globally, crocodilians are a useful system for developing long-term carnivore conservation schemes. Salt-water crocodiles Crocodylus porosus are distributed across South-east Asia and are considered to be a significant threat to humans (CrocBITE, 2016). A large proportion of attacks by $C$. porosus occur in Indonesia, and many of these occur in the Greater Sunda region. Crocodylus porosus is listed in CITES Appendix II (CITES, 2017), and in Indonesia harvesting of wild adults is legal only from the eastern province of Papua, although the collection of eggs and juveniles from Kalimantan and Sumatra has been legalized (Webb et al., 2010). Crocodylus porosus is categorized as Lower Risk/Least Concern on the IUCN Red List (Crocodile Specialist Group, 1996) but its population status across most of Indonesia is unknown (Webb et al., 2010).

The false gharial Tomistoma schlegelii also inhabits the Greater Sunda region and is considered to be one of the least known crocodilians (Bezuijen et al., 1995, 1997, 2001; Auliya et al., 2006; Stuebing et al., 2006; Simpson, 2014). It primarily inhabits black-water, peat swamp forest, although most lowland swamp forest in the region has been lost as a result of deforestation (Sodhi et al., 2004; 
Miettinen et al., 2014). Tomistoma schlegelii is listed in CITES Appendix I (CITES, 2017) and is categorized as Vulnerable on the IUCN Red List (Bezuijen et al., 2014). Prior to an update in 2014 it was categorized as Endangered but despite the status update, data on the species' population status are sparse across much of its range, particulalry in Sumatra. Although significant work has been conducted on T. schlegelii (J. Cox et al., unpubl. data; Bezuijen et al., 1995, 1997, 2001, 2002), only c. 100 confirmed sightings of the species have been recorded in Sumatra (Stuebing et al., 2006), and to the best of our knowledge no crocodilian surveys have been conducted in Sumatra since 2002 (Bezuijen et al., 2002).

We gathered population data on C. porosus and T. schlegelii in areas of Sumatra that have and have not been assessed previously for crocodilian abundance. We examined whether crocodilian abundance was negatively influenced by proximity to humans and whether crocodiles were capable of persisting in areas of high human disturbance. We also examined whether fish-trapping activity was associated with declines in crocodilian abundance. We predicted that increased fish-trapping activity and proximity to humans would be associated with declines in crocodile abundance. We used species distribution modelling techniques to identify potential remaining suitable habitat for T. schlegelii across its range and suggest key areas for conservation priority.

\section{Study areas}

Crocodylus porosus is distributed across northern Australia and South-east Asia, whereas T. schlegelii is restricted to the Greater Sunda region. Our work focused on these two species in four study areas on the island of Sumatra (Fig. 1): the Air Hitam Laut River system in Berbak National Park (previously surveyed), the Lower Kampar River system (not previously surveyed), the Simpang Kanan River system (not previously surveyed), and the Lalan River system (previously surveyed). We conducted surveys during June-August in 2014 and 2015. The Lalan River and Simpang Kanan River systems were surveyed in 2014, the Air Hitam Laut River system was surveyed in 2015, and the Lower Kampar River was surveyed during both field seasons.

Berbak National Park, in the south-east of Jambi Province (Fig. 1b), was surveyed previously by J. Cox (1990, unpubl. data) and Bezuijen et al. $(1997,2002)$. It includes one of the largest remaining tracts of peat swamp forest habitat in Sumatra. Two distinct seasons, wet and dry, affect water levels in the peat swamp forests (lowland acidic swamp) of the region. In Sumatra the wet season typically lasts from October until late February, and large sections of the forest become flooded during this time. In the dry season, during March-September, the forests progressively dry

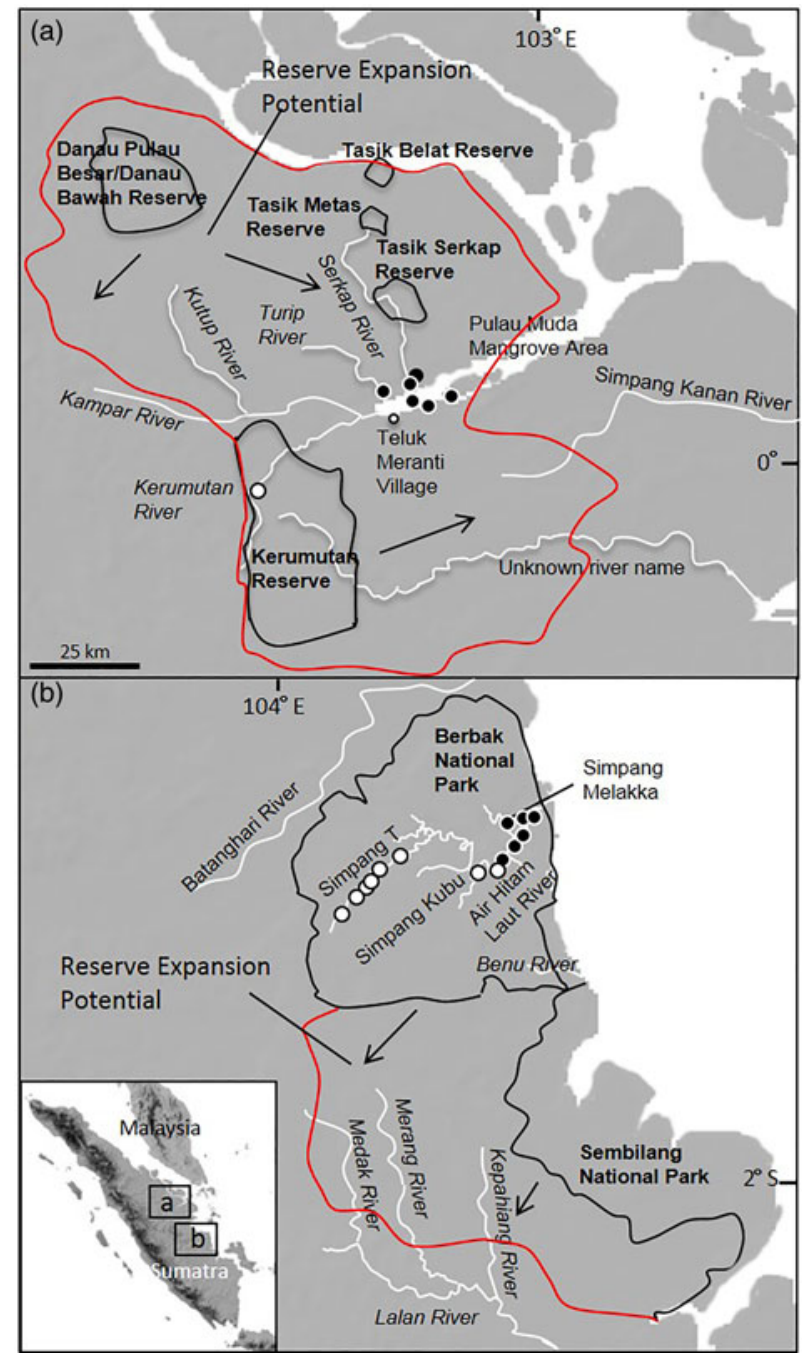

FIG. 1 (a) Lower Kampar River and Simpang Kanan study areas (previously unsurveyed), and (b) Berbak National Park and Merang River study areas (previously surveyed). Locations of sightings of salt-water crocodiles Crocodylus porosus (black filled circles) and false gharials Tomistoma schlegelii (white filled circles) are marked, and all parks and reserves are delineated, as are areas with potential for reserve expansion.

up. By mid August only the main tributaries, billabongs and lakes still hold water. The Park is intersected by the Air Hitam Laut River system and encompasses branches of the Batanghari River in the north (Air Hitam Dalam Tributary, not surveyed here) and Benu River in the south (not surveyed here). Logging and hunting activities are illegal within the Park boundaries; however, illegal activity has penetrated the perimeter of the Park in multiple locations.

The Lower Kampar River encompasses some of the last remaining patches of primary peat swamp forest in Riau Province (Fig. 1a) and has not been surveyed previously for crocodiles. Multiple black-water tributaries originate in the surrounding forests and enter the river at various 
locations immediately east and west of Teluk Meranti village (Shaney et al., 2015). Major tributaries in the area include the Kerumutan, Kutup, Serkap and Turip Rivers. Two small reserves are located along the Serkap River (Tasik Metas and Tasik Serkap Reserves) and there is a larger reserve along the Kerumutan River (Kerumutan Reserve). Reserves in the area are rarely monitored by wildlife officials, and illegal logging, fishing and hunting activity occur. We also surveyed the Simpang Kanan River, which originates within the peat swamp forest adjacent to the Kerumutan Reserve; however, the river drains directly into the ocean rather than into the Lower Kampar River (Fig. 1a). The Simpang Kanan River had not been surveyed prior to our study.

Our final survey area included the Lalan River system, with a particular focus on the Merang River. The headwaters of the Merang River originate near the Berbak National Park study area; however, the river drains to the south, entering the Lalan River system in South Sumatra Province (Fig. 1b). Amongst Sumatran rivers the Merang River has received the most survey attention for T. schlegelii activity in the past, and the majority of historical T. schlegelii sightings in Sumatra have been recorded in this river (Stuebing et al., 2006). Bezuijen et al. $(1995,1997,2001)$ and Shaney et al. (2015) provide detailed information about the study area.

\section{Methods}

Surveys

Surveys followed techniques from Bayliss (1987) and Bezuijen et al. (1997, 2001). Night-time spotlight surveys were conducted along sections of the main Kampar River (54.8 $\mathrm{km}$ surveyed) and on four tributaries of the Lower Kampar River system: Kerumutan River (22 km surveyed), Kutup River (2 km surveyed), Serkap River (41.2 km surveyed) and Turip River (11.2 km surveyed). We also surveyed sections of the Air Hitam Laut River (27.3 km surveyed) and nearby Kumpe River (16.1 km surveyed), as well as tributaries of the Air Hitam Laut River system: Simpang Kubu (4.6 km surveyed), Simpang Melakka (11.4 km surveyed) and Simpang T (8.7 km surveyed). We surveyed $40.8 \mathrm{~km}$ of the Merang River (Lalan River System), $25 \mathrm{~km}$ of the main Lalan River and $45 \mathrm{~km}$ of the Simpang Kanan River (Fig. 1). Start and end points of transects were recorded using a global positioning system. Transect lengths were recorded and used to determine the number of crocodiles sighted per $\mathrm{km}$ of river surveyed. Repeat surveys were conducted only in three locations (Kerumutan, Serkap and Turip Rivers) and we subtracted potential repeat sightings from total counts. A total of $326.2 \mathrm{~km}$ of river was surveyed: $60 \mathrm{~km}$ by paddle boat and $266.2 \mathrm{~km}$ with the aid of small motors. A total of 26 survey nights and 40 days were spent in the study areas. Twelve survey nights were spent on the Air Hitam Laut River system, 12 on the Lower Kampar River system, 1 on the Simpang Kanan River and 1 on the Lower Merang River.

We used a wooden boat ( $5 \mathrm{~m}$ length) with a $25 \mathrm{hp}$ motor on larger rivers, and canoes ( $4 \mathrm{~m}$ length) on small tributaries. We traversed transects during the day to record ecological and dependent variables for statistical analyses. Surveys were typically initiated 30-60 minutes after nightfall (18.30-19.30). In tidally influenced areas we altered survey start times accordingly. In upper tributaries unaffected by tide, water levels were relatively low and did not extend into fringing vegetation. We recorded $\mathrm{pH}$ levels at the beginning and end of each transect, and when a crocodile was observed we noted the $\mathrm{pH}$ measurement recorded closest to the sighting. Crocodile eye-shine was detected using 10,0oo lumen headlamps. When we sighted a crocodile we approached it and, when possible, identified the species and recorded the age class. We defined crocodiles by the following age classes: hatchling (young of that year, c. 0.3-0.6 m), juvenile (not yet sexually mature, c. 0.6-2.1 m), and adult (sexually mature, $>2.1 \mathrm{~m}$ ). When crocodiles submerged before further identification could be made we recorded the sighting as an eye-shine, or as probable species identification if we were confident in the identification despite only catching a glimpse of the crocodile.

\section{Statistical analysis}

Survey results from the four major river systems and nine of their tributaries were included in analyses. The dependent variables associated with our crocodile data included confirmed crocodile species identification counts, probable species identification counts, confirmed species identification counts and daytime sign (description of daytime data below), and probable species identification counts and daytime sign. We also tested for varying effects on each age class and combined species counts because of low sample size. Poisson log-linear regressions were used to test the factors associated with variation in crocodile abundance, using SPSS v. 21 (IBM, Armonk, USA). We tested whether crocodiles were more likely to be found in remote areas, using distance from human inhabitance as a quantifiable measure. We measured Euclidian, or straight-line, distance between each sighting and the nearest village, and then we measured the distance along the centre-line of rivers between each sighting and the nearest village (i.e. river distance). We identified villages with $>_{500}$ residents as a cut-off point for selecting the nearest village to each sighting, following Stoner et al. (2013). Next, we tested whether fish-trapping pressure was negatively correlated with crocodile abundance. To accomplish this we counted fish traps along transects and used the number of fish traps per $\mathrm{km}$ as a predictor variable. We also identified habitat preferences, based on sightings of 
each species, and partitioned sightings into four habitat categories: (1) primary forest (forest that appears to be unaltered), (2) secondary forest (regrowth after logging), (3) mangrove forest, and (4) no forest. We identified habitat types along the edges of waterways where crocodiles were sighted, and confirmed habitat types using land-cover data in ArcMap 10.3 (ESRI, Redlands, USA). We used a twotailed t-test to test for interspecific habitat partitioning, using $\mathrm{pH}$ levels associated with sightings (night-time sightings only: $\mathrm{n}=42$ for $C$. porosus and $\mathrm{n}=15$ for $T$. schlegelii; night and daytime sightings combined: $\mathrm{n}=43$ for $C$. porosus and $\mathrm{n}=21$ for $T$. schlegelii). The daytime data included each unique locality where crocodiles were seen during the day or where we collected bones or eggshells, or saw slide marks (see Plate 1 for examples of both night-time and daytime data). Datasets with and without daytime data were analysed independently. We tested for possible multicollinearity between variables using collinearity statistics in SPSS.

\section{Species distribution modelling}

We used Maxent 3.3.3k (Phillips et al., 2016) to model suitable T. schlegelii habitat across the Greater Sunda region. We focused only on T. schlegelii for this analysis because it is categorized as Vulnerable across its range. We created four species distribution models to compare and contrast variable effects on potential distribution: (1) climate layers (19 bioclim layers; WorldClim, 2016), (2) climate layers + landcover, (3) climate layers + human population density, (4) climate layers + land-cover + human population density. Human population density and land-cover layers (all at 30-second resolution) were acquired from DIVA-GIS (2015). We used all confirmed records of T. schlegelii in Auliya et al. (2006), Stuebing et al. (2006) and Bonke et al. (2008), data from East Kalimantan (A. Staniewicz, unpubl. data), and our own survey data. Collinearity is not considered to be problematic when using Maxent, and therefore we did not exclude any variables after model testing (Elith et al., 2011); however, we conducted jackknife tests to determine which variables were most predictive of T. schlegelii distribution. We used the Auto Features settings provided, changed the number of iterations to 5,000, replicated run type to subsample, and set random test percentage to 25 . We assessed the area under the curve (AUC) for each model, to measure model performance using the presence localities provided. AUC models are produced in Maxent only when test values are provided. AUC values closer to 1.0 indicate high performance of the predictive suitability models. We then extracted areas from the species distribution models that intersected with rivers and inland water bodies (DIVA-GIS, 2015), because T. schlegelii is aquatic. We quantified the amount of suitable aquatic habitat across the species' range with a probability of occurrence $>0.2$ to be conservative. We also distinguished other break points at $0.4,0.6$ and 0.8 , for context. Although T. schlegelii was recorded in disturbed habitat, the majority of sightings occurred in unfragmented primary lowland forest. Therefore, we also extracted suitable habitat from within remaining primary lowland forest areas and quantified those areas separately. We restricted final quantifications with a polygon mask, excluding biogeographical areas beyond the species' range. We repeated these steps explicitly for Sumatra.

\section{Results}

\section{Survey data}

A total of 57 crocodiles (C. porosus and T. schlegelii combined) were counted (eye-shine only) during night-time surveys, and eight signs of crocodile presence were found during the day (Table 1). We recorded 42 sightings on the Air Hitam Laut River and 15 on the Lower Kampar River. No crocodilian sightings were recorded in the Lalan or Simpang Kanan Rivers. In total, eight sightings were confirmed as T. schlegelii and 15 were probably T. schlegelii, and seven signs of $T$. schlegelii were recorded during the daytime; an increase compared to previous records of T. schlegelii in Sumatra. The Simpang T tributary of the Air Hitam Laut River has not been mentioned in previously published data, but this was where we recorded 12 of the 14 T. schlegelii sightings in the Air Hitam Laut River system. We recovered a single, dead juvenile $T$. schlegelii in Kerumutan Village along the Kerumutan River, which is the first confirmed record of $T$. schlegelii from the Kerumutan River and from the Lower Kampar River system in general. For details of all sighting localities see Shaney et al. (2016). For a comparison of species densities from this study with findings of previous studies conducted in the Air Hitam Laut and Lalan River systems see Table 2.

\section{Poisson regressions}

Measures of collinearity indicated that fish-trapping activity and remoteness (i.e. distance to human settlements) were independent measures (collinearity statistics: tolerance value $=0.998$, variance inflation factor $=1.002$ ). We observed significant $(\mathrm{P}<0.05)$ effects of remoteness and fishtrapping activity on crocodile abundance (Table 3 ). Fish trap density was a significant predictor of crocodile counts for six out of eight estimates of crocodile abundance, and remoteness was a significant predictor of crocodile counts in all analyses (Table 3). For all significant trends T. schlegelii and C. porosus counts were positively correlated with increasing distance from human inhabitance (high 


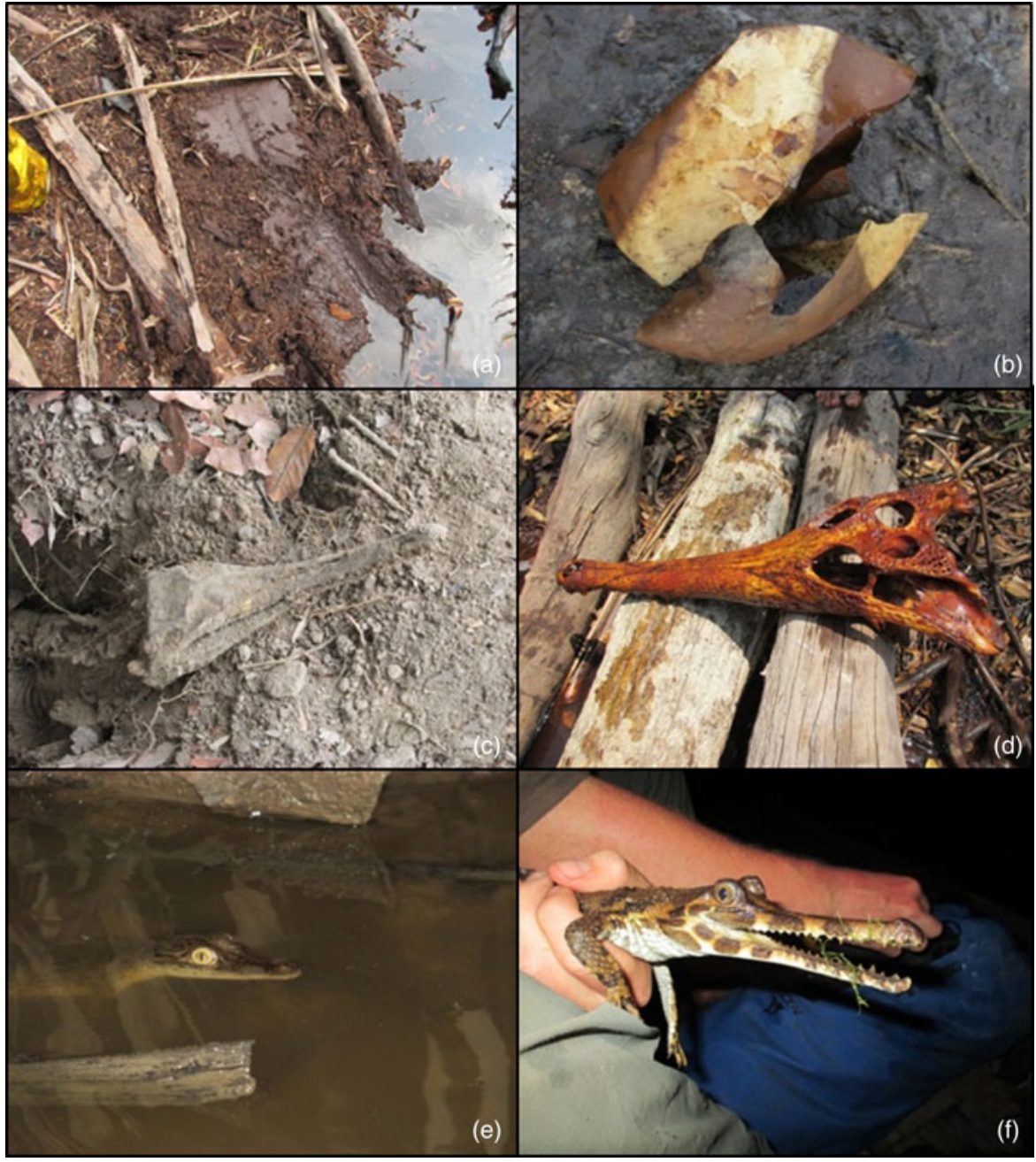

Plate 1 Examples of crocodile sightings or crocodile sign.

(a) Daytime slide mark in the mud,

(b) Tomistoma schlegelii eggshell (measurements confirm this), (c) dead T. schlegelii, (d) T. schlegelii skull, (e) hatchling Crocodylus porosus, (f) hatchling T. schlegelii. remoteness increases the likelihood of seeing crocodiles) and negatively correlated with increasing fish trap density.

\section{Age class}

We evaluated separately the effects of human activities and fishing pressure on age classes. Hatchlings and adults were significantly more likely to be found in remote areas, and hatchlings were more likely to be found in areas with low fish-trapping activity (Table 3 ). We could not test whether fish-trapping activity had an effect on juveniles or adults because there was no variation in those data (e.g. zero fish traps along transects where adults and juveniles were found).

\section{Habitat preferences and habitat partitioning}

We identified habitat partitioning between crocodile species ( $\mathrm{P}<\mathrm{0.01}$ ). Crocodylus porosus was more likely to be found in secondary forest, whereas T. schlegelii was more likely to be found in primary forest (Table 4 ). Changes in $\mathrm{pH}$ in the
Air Hitam Laut River coincided with abrupt shifts in crocodile presence/absence (Fig. 1); $\mathrm{pH}$ decreased from 6.5 to 4.5 along the junctions of black water tributaries and saline environments. Tomistoma schlegelii was significantly more likely to be found in water with low $\mathrm{pH}(4.5-4.8)$ and C. porosus was significantly more likely to be found in water with high $\mathrm{pH}(5.0-6.5)$.

\section{Habitat suitability}

All four species distribution models for T. schlegelii identified approximately the same suitable areas and returned similar AUC values (training data: 0.95-0.96; test data: o.88-0.89). Therefore, we assess the most conservative model here (Model 4), which modelled the largest amount of suitable habitat and included all habitat variables (climate + landcover + human population density). Model 4 identified $22,396.07 \mathrm{~km}^{2}$ of suitable habitat across the species' range ( $>0.2$ probability of occurrence), of which $3,772.6 \mathrm{~km}^{2}$ falls within remaining primary lowland forest (Fig. 2). Of this suitable habitat, $17,820.06 \mathrm{~km}^{2}$ 
TABLE 1 Counts and densities of crocodiles (Tomistoma schlegelii and Crocodylus porosus; confirmed and probable combined) in the Lower Kampar, Air Hitam Laut, Simpang Kanan and Lalan River systems in Sumatra, Indonesia (Fig. 1), with additional records of eye-shines (species unidentified).

\begin{tabular}{|c|c|c|c|c|c|c|}
\hline & \multirow[b]{2}{*}{ Stretch of river surveyed $(\mathrm{km})$} & \multicolumn{2}{|c|}{ No. of individuals } & \multicolumn{2}{|c|}{ Density (individuals $\mathrm{km}^{-1}$ ) } & \multirow[b]{2}{*}{ Eye-shines } \\
\hline & & T. schlegelii & C. porosus & T. schlegelii & C. porosus & \\
\hline \multicolumn{7}{|l|}{ Lower Kampar River system } \\
\hline Serkap River & $0-41.2$ & 0 & 8 & 0 & 0.19 & 1 \\
\hline Main Kampar River & $30-84.8$ & 0 & 2 & 0 & 0.037 & 0 \\
\hline Kerumutan River & $0-22$ & 0 & 1 & 0 & 0.046 & 0 \\
\hline Turip River & $0-11.2$ & 0 & 3 & 0 & 0.27 & 0 \\
\hline Kutup River & $0-2$ & 0 & 0 & 0 & 0 & 0 \\
\hline Total & 131.2 & 0 & 14 & & & 1 \\
\hline \multicolumn{7}{|l|}{ Air Hitam Laut River system } \\
\hline Main Air Hitam Laut River & $0-27.3$ & 3 & 26 & 0.11 & 0.95 & 0 \\
\hline Simpang Melakka & $0-11.4$ & 0 & 1 & 0 & 0.09 & 0 \\
\hline Simpang Kubu & $0-4.6$ & 0 & 0 & 0 & 0 & 0 \\
\hline Simpang $T$ & $0-8.7$ & 12 & 0 & 1.38 & 0 & 0 \\
\hline Kumpe River* & $0-16.1$ & 0 & 0 & 0 & 0 & 0 \\
\hline Total & 68.1 & 15 & 27 & & & 0 \\
\hline \multicolumn{7}{|l|}{ Simpang Kanan River system } \\
\hline Main Simpang Kanan River & $30-75$ & 0 & 0 & 0 & 0 & 0 \\
\hline Ocean mangroves & $\begin{array}{l}\text { Mouth of Simpang Kanan } \\
\text { River-16.1 south }\end{array}$ & 0 & 0 & 0 & 0 & 0 \\
\hline Total & 61.1 & 0 & 0 & 0 & 0 & 0 \\
\hline \multicolumn{7}{|l|}{ Lalan River system } \\
\hline Main Lalan River & $65-90$ & 0 & 0 & 0 & 0 & 0 \\
\hline Merang River & $0-40.8$ & 0 & 0 & 0 & 0 & 0 \\
\hline Total & 65.8 & 0 & 0 & 0 & 0 & 0 \\
\hline Grand total & 326.2 & 15 & 41 & & & 1 \\
\hline
\end{tabular}

${ }^{\star}$ River adjacent to main river system

$\left(3,356.31 \mathrm{~km}^{2}\right.$ primary lowland forest) falls within Indonesia, $3,862.74 \mathrm{~km}^{2}$ (196.99 $\mathrm{km}^{2}$ primary lowland forest) within Malaysia, and $713.27 \mathrm{~km}^{2}$ (219.3 $\mathrm{km}^{2}$ primary lowland forest) within Brunei. From these data we estimate that c. $10,558 \mathrm{~km}^{2}$ of suitable habitat remains in Sumatra, of which only $1,548.98 \mathrm{~km}^{2}$ falls within remaining primary lowland forest. All values reflect only where suitable habitat and waterways overlap. Our model returned four key areas for T. schlegelii conservation in Sumatra and six in Borneo.

\section{Discussion}

Given the critical need for crocodilian conservation efforts in Indonesia, we consider these data to be valuable to the conservation of $T$. schlegelii and $C$. porosus, and more broadly to the conservation and management of vertebrates, considering the shifting biogeography of South-east Asia. The Balai Konservasi Sumber Daya Alam (Natural Resources Conservation Agency) currently regulates animal harvest quotas in Indonesia and is in the process of considering new harvest regulations for $C$. porosus across the archipelago. We suggest several key conservation priorities for crocodilians in the Greater Sunda region.

\section{Habitat partitioning}

We identified clear habitat partitioning between crocodile species, which confirms the findings of others (Bezuijen et al., 2001; Auliya et al., 2006). Crocodylus porosus was found along the coastline and in brackish environments, whereas T. schlegelii was restricted to freshwater, in black water tributaries. We found the species coincided along a transitional $\mathrm{pH}$ zone (interspecific sightings only $2 \mathrm{~km}$ apart) on the Air Hitam Laut River. The location where species composition changes along the river is where saltwater Nypa palms transition into freshwater Pandanus palms, and $\mathrm{pH}$ changes substantially (Fig. 1b). In many parts of its range C. porosus is found far upriver in freshwater environments. Conversely, T. schlegelii is not known to inhabit saline environments. Further investigation of the relationship between C. porosus and T. schlegelii could yield information regarding competition between these two large crocodilian species. For example, how does the relationship between the two species change seasonally (e.g. in the wet season, when $C$. porosus often travels far upriver in other parts of its range)? Also, do these species commonly engage in intraguild predation? Answering these questions could also inform future management approaches. 
TABLE 2 Details of all crocodilian sightings during surveys of four river systems in Sumatra, Indonesia (Fig. 1), (this study) and those reported in previous studies, with length of river surveyed; numbers of hatchlings, juveniles, adults, and eye-shine; density (including and excluding counts of eye-shine); and data source. Age classes taken from Bezuijen et al. (1995, 1997, 2001, 2002) are adapted to age class from foot class data. Bezuijen et al. $(1995,1997)$ foot classes of $>6$ feet are included as adults in this table.

\begin{tabular}{|c|c|c|c|c|c|c|c|c|c|}
\hline \multirow[b]{2}{*}{ River } & \multirow{2}{*}{$\begin{array}{l}\text { Stretch of } \\
\text { river } \\
\text { surveyed } \\
(\mathrm{km})\end{array}$} & \multicolumn{5}{|c|}{ No. of records } & \multicolumn{2}{|c|}{ Density (individuals $\mathrm{km}^{-1}$ ) } & \multirow[b]{2}{*}{ Source } \\
\hline & & Hatchlings & Juveniles & Adults & Eye-shine & Total & $\begin{array}{l}\text { Including } \\
\text { eye-shine } \\
\text { counts }\end{array}$ & $\begin{array}{l}\text { Excluding } \\
\text { eye-shine } \\
\text { counts }\end{array}$ & \\
\hline \multicolumn{10}{|c|}{$\begin{array}{l}\text { Air Hitam Laut River } \\
\text { system }\end{array}$} \\
\hline \multicolumn{10}{|c|}{ Air Hitam Laut River } \\
\hline 1990 & $0-20.5$ & \multicolumn{4}{|c|}{$\begin{array}{l}7 \text { false gharials Tomistoma schlegelii seen, no } \\
\text { size reported }\end{array}$} & 7 & 0.34 & 0.34 & $\begin{array}{l}\text { J. Cox (un- } \\
\text { publ. data) }\end{array}$ \\
\hline 1996 & $0-25$ & 0 & 1 & 1 & 2 & 4 & 0.16 & 0.08 & $\begin{array}{l}\text { Bezuijen et al. } \\
\text { (1997) }\end{array}$ \\
\hline 2001 & $0-31$ & 1 & 0 & 0 & 3 & 4 & 0.13 & 0.03 & $\begin{array}{l}\text { Bezuijen et al. } \\
\text { (2001) }\end{array}$ \\
\hline 2002 & $0-32$ & & 1 & 0 & 3 & 4 & 0.13 & 0.03 & $\begin{array}{l}\text { Bezuijen et al. } \\
\text { (2002) }\end{array}$ \\
\hline 2015 & $0-27.3$ & 1 & 1 & 1 & 0 & 3 & 0.11 & 0.11 & This study \\
\hline \multicolumn{10}{|c|}{ Simpang Melaka Creek } \\
\hline 1996 & $0-2$ & 0 & 1 & 0 & 2 & 3 & 1.5 & 0.5 & $\begin{array}{l}\text { Bezuijen et al. } \\
\text { (1997) }\end{array}$ \\
\hline 2001 & $0-7.2$ & 2 & 1 & 0 & 2 & 5 & 0.69 & 0.4 & $\begin{array}{l}\text { Bezuijen et al. } \\
\text { (2001) }\end{array}$ \\
\hline 2002 & $0-7.2$ & 0 & 0 & 0 & 1 & 1 & 0.14 & 0 & $\begin{array}{l}\text { Bezuijen et al. } \\
\text { (2002) }\end{array}$ \\
\hline 2015 & $0-11.4$ & 0 & 0 & 0 & 1 & 1 & 0.09 & 0 & This study \\
\hline \multicolumn{10}{|l|}{ Simpang Kubu } \\
\hline 2015 & $0-4.6$ & 0 & 0 & 0 & 0 & 0 & & & This study \\
\hline \multicolumn{10}{|l|}{ Simpang $\mathrm{T}$} \\
\hline 2015 & $0-8.7$ & 3 & 5 & 4 & 0 & 12 & 1.379 & 1.379 & This study \\
\hline \multicolumn{10}{|l|}{ Lalan River system } \\
\hline \multicolumn{10}{|l|}{ Lalan River } \\
\hline 1990 & $0-150$ & $\begin{array}{l}2 T . \text { schleg } \\
\text { reported }\end{array}$ & elii seen, & no size & 2 & 4 & 0.03 & 0.01 & $\begin{array}{l}\text { J. Cox (un- } \\
\text { publ. data) }\end{array}$ \\
\hline 1995 & $0-160$ & 0 & 0 & 0 & 0 & 0 & 0 & 0 & $\begin{array}{l}\text { Bezuijen et al. } \\
\text { (1995) }\end{array}$ \\
\hline 2014 & $80-140$ & 0 & 0 & 0 & 0 & 0 & 0 & 0 & This study \\
\hline Kepahyang & $0-16.5$ & 0 & 0 & 0 & 0 & 0 & 0 & 0 & $\begin{array}{l}\text { Bezuijen et al. } \\
(1995)\end{array}$ \\
\hline \multicolumn{10}{|l|}{ Medak River } \\
\hline 1990 & $0-8$ & 0 & 0 & 0 & 0 & 0 & 0 & 0 & $\begin{array}{l}\text { J. Cox (un- } \\
\text { publ. data) }\end{array}$ \\
\hline 1995 & $0-53$ & 0 & 0 & 2 & 0 & 2 & 0.03 & 0.03 & $\begin{array}{l}\text { Bezuijen et al. } \\
(1995)\end{array}$ \\
\hline $\begin{array}{l}\text { Medak River upper } \\
\text { tributaries }\end{array}$ & $\begin{array}{l}\text { See } \\
\text { Bezuijen } \\
\text { et al. } \\
(1995)\end{array}$ & 0 & 0 & 0 & 0 & 0 & 0 & 0 & $\begin{array}{l}\text { Bezuijen et al. } \\
(1995)\end{array}$ \\
\hline \multicolumn{10}{|l|}{ Merang River } \\
\hline 1990 & $0-45$ & 1 T. schlegel & $i$ seen, no & size repor & ted & 1 & 0.04 & 0.07 & $\begin{array}{l}\text { J. Cox (un- } \\
\text { publ. data) }\end{array}$ \\
\hline 1995 & $0-45$ & 0 & 4 & 0 & 3 & 7 & 0.16 & 0.09 & $\begin{array}{l}\text { Bezuijen et al. } \\
\text { (1995) }\end{array}$ \\
\hline 1996 & $0-45$ & 0 & 1 & 0 & 1 & 2 & 0.04 & 0.02 & $\begin{array}{l}\text { Bezuijen et al. } \\
\text { (1997) }\end{array}$ \\
\hline
\end{tabular}


Table 2 (Cont.)

\begin{tabular}{|c|c|c|c|c|c|c|c|c|c|}
\hline \multirow[b]{2}{*}{ River } & \multirow{2}{*}{$\begin{array}{l}\text { Stretch of } \\
\text { river } \\
\text { surveyed } \\
(\mathrm{km})\end{array}$} & \multicolumn{5}{|c|}{ No. of records } & \multicolumn{2}{|c|}{ Density (individuals $\mathrm{km}^{-1}$ ) } & \multirow[b]{2}{*}{ Source } \\
\hline & & Hatchlings & Juveniles & Adults & Eye-shine & Total & $\begin{array}{l}\text { Including } \\
\text { eye-shine } \\
\text { counts }\end{array}$ & $\begin{array}{l}\text { Excluding } \\
\text { eye-shine } \\
\text { counts }\end{array}$ & \\
\hline 2001 & $0-45$ & 0 & 4 & 0 & 0 & 4 & 0.09 & 0.09 & $\begin{array}{l}\text { Bezuijen et al } \\
(2001)\end{array}$ \\
\hline 2002 & $0-45$ & 0 & 1 & 0 & 0 & 1 & 0.04 & 0.02 & $\begin{array}{l}\text { Bezuijen et al } \\
\text { (2002) }\end{array}$ \\
\hline 2014 & $0-45$ & 0 & 0 & 0 & 0 & 0 & 0 & 0 & This study \\
\hline \multicolumn{10}{|c|}{ Merang River } \\
\hline 1995 & $45-67$ & 0 & 2 & 0 & 5 & 7 & 0.34 & 0.09 & $\begin{array}{l}\text { Bezuijen et al } \\
\text { (1995) }\end{array}$ \\
\hline 1996 & $45-67$ & 0 & 4 & 1 & 5 & 10 & 0.49 & 0.23 & $\begin{array}{l}\text { Bezuijen et al } \\
\text { (1997) }\end{array}$ \\
\hline 2001 & $45-67$ & 1 & 12 & 0 & 1 & 14 & 0.64 & 0.6 & $\begin{array}{l}\text { Bezuijen et al } \\
(2001)\end{array}$ \\
\hline 2002 & $45-67$ & 0 & 0 & 0 & 2 & 2 & 0.16 & 0 & $\begin{array}{l}\text { Bezuijen et al } \\
(2002)\end{array}$ \\
\hline
\end{tabular}

\section{Human disturbance}

Abundance of both C. porosus and T. schlegelii is correlated negatively with proximity to humans (although C. porosus was found in disturbed habitat). We also found that common fish-trapping methods throughout the region were negatively associated with crocodile abundance. It is important to consider that the correlations we identified do not necessarily indicate causation. There are other factors that could potentially affect crocodilian abundance that are cross-correlated with the independent variables we tested. We interpret our results with this in mind. We suggest future surveys target remote locations, and management officials consider eliminating fish trapping from areas of core crocodile habitat. Despite the difficulties involved, trapping has already been successfully eliminated from one section of Berbak National Park, along the Simpang $\mathrm{T}$ tributary of the Air Hitam Laut River (Fig. 1b). Because fish trapping yields important resources for many local communities, regulations requiring woven box or funnel traps (rather than netting) with access to air for crocodile bycatch could be implemented, rather than complete elimination of fish trapping in key areas.

\section{Crocodilian population assessments and suitable habitat}

Crocodylus porosus population densities were relatively low across our study areas. Additionally, C. porosus densities in the Air Hitam Laut River system mostly comprised hatchlings, many of which were in close proximity to each other.
This suggests that many individuals were of the same clutches, and given the low hatchling survival rate the actual density of $C$. porosus is probably much lower, and more representative of a few adults that had separate clutches along the river. We recommend C. porosus population surveys be conducted across other parts of Sumatra on an ongoing basis. This is particularly important given recent changes to $C$. porosus management in Indonesia, in which the taking of eggs and juveniles from Sumatra will be permitted (Brien et al., 2015). Sembilang National Park has never been surveyed for crocodilian abundance but it could potentially hold large populations of $C$. porosus, as it encompasses large swaths of intact mangrove forest along the east coast of Sumatra. Multiple C. porosus individuals were encountered in the Lower Kampar River, particularly at the mouths of blackwater tributaries and in sections of mangrove near the coast. Thus, we suggest surveys targeted on the far eastern portion of the Lower Kampar River could yield high densities of $C$. porosus, and the area could be important for the long-term viability of the species. Other regions, such as the Bangka Islands and Riau province coastline, seem to hold relatively large populations of C. porosus, based on numbers of reported attacks on people, but require scientific surveys for population density estimates. We also suggest repeat surveys be conducted frequently on the Air Hitam Laut and Lower Kampar Rivers.

Tomistoma schlegelii populations in Sumatra appear to be fragmented, occurring in potentially fewer than five locations. Extant subpopulations are confirmed at only three locations in Sumatra (Air Hitam Laut, Lalan and Lower 
TABLE 3 Statistical model outcomes after testing for effects of remoteness and fish-trap density on crocodilian counts, with sample sizes $(\mathrm{N})$ and $\mathrm{P}$ values. Data are separated according to whether sightings were confirmed or probable, and by age class. Bold font signifies statistically significant values.

\begin{tabular}{|c|c|c|c|}
\hline Model data & $\mathrm{N}$ & P (Remoteness) & $\begin{array}{l}\mathrm{P} \text { (Fish-trap } \\
\text { density) }\end{array}$ \\
\hline Confirmed T. schlegelii & 8 & $<\mathbf{0 . 0 1}$ & $<\mathbf{0 . 0 1}$ \\
\hline Probable T. schlegelii & 15 & 0.01 & 0.01 \\
\hline Confirmed T. schlegelii* & 20 & 0.01 & 0.01 \\
\hline Probable T. schlegelii* & 22 & $<\mathbf{0 . 0 1}$ & $<\mathbf{0 . 0 1}$ \\
\hline Confirmed C. porosus & 32 & 0.01 & 0.1 \\
\hline Probable C. porosus & 41 & $<\mathbf{0 . 0 1}$ & 0.03 \\
\hline Confirmed C. porosus ${ }^{\star}$ & 33 & 0.01 & 0.112 \\
\hline Probable C. porosus ${ }^{\star}$ & 42 & $<\mathbf{0 . 0 1}$ & 0.04 \\
\hline $\begin{array}{l}\text { Hatchling crocodiles } \\
\text { (species combined) }\end{array}$ & 38 & 0.02 & 0.05 \\
\hline $\begin{array}{l}\text { Juvenile crocodiles } \\
\text { (species combined) }\end{array}$ & 18 & 0.695 & \\
\hline $\begin{array}{l}\text { Adult crocodiles (species } \\
\text { combined) }\end{array}$ & 10 & 0.02 & \\
\hline
\end{tabular}

${ }^{*}$ Partitioned data with daytime sign included in counts

Kampar Rivers), which are all isolated by distance and terrain, meaning it is unlikely individuals will travel across large tracts of unfavourable habitat between populations to increase gene flow. Although we recorded the first record of $T$. schlegelii in the Kerumutan River, we confirmed the presence of only a single individual. This suggests that T. schlegelii densities may be relatively low in the Lower Kampar River system. We suggest focusing future survey efforts on the upper reaches of the Kerumutan River, including a tributary suggested by local people, known as the Eka River (Fig. 1). The Eka River has never been surveyed but may hold higher numbers of $T$. schlegelii than other sections of the lower Kerumutan River. We also suggest the upper reaches of the Serkap River, near Tasik Metas Reserve, and the upper reaches of the Kutup River be surveyed (Fig. 1). Given time limitations and the logistical challenges involved we could not survey the far upper reaches of those tributaries, which could hold T. schlegelii populations (based on remoteness and habitat characteristics). The Air Hitam Laut River still has a relatively high density of $T$. schlegelii and should be considered to be critical to the persistence of the species in Sumatra. The upper Air Hitam Laut River, particularly the Simpang T tributary, had the highest densities of $T$. schlegelii recorded anywhere in Berbak National Park, and these remote tributaries require continued protection. Overall, we recorded T. schlegelii densities similar to those found in previous surveys conducted on the main Air Hitam Laut River and lower Simpang Melaka Creek (Bezuijen et al., 1995, 1997, 2001, 2002). Tomistoma schlegelii density in Simpang $\mathrm{T}$ tributary was
TABLE 4 Species habitat preferences across all study areas, with numbers in bold indicating a preference of $C$. porosus for secondary forest and of T. schlegelii for primary forest.

\begin{tabular}{lllll}
\hline Species & $\begin{array}{l}\text { Primary } \\
\text { forest (N) }\end{array}$ & $\begin{array}{l}\text { Secondary } \\
\text { forest (N) }\end{array}$ & $\begin{array}{l}\text { Mangrove } \\
\text { forest (N) }\end{array}$ & $\begin{array}{l}\text { No forest } \\
(\mathrm{N})\end{array}$ \\
\hline $\begin{array}{l}\text { C. porosus } \\
\text { confirmed }\end{array}$ & 5 & $\mathbf{2 3}$ & 1 & 0 \\
$\begin{array}{l}\text { C. porosus } \\
\text { probable }\end{array}$ & 9 & $\mathbf{3 2}$ & 1 & 0 \\
$\begin{array}{l}\text { C. porosus } \\
\text { confirmed }\end{array}$ & 5 & $\mathbf{2 4}$ & 1 & 0 \\
$\begin{array}{l}\text { C. porosus } \\
\text { probable }\end{array}$ & 9 & $\mathbf{3 3}$ & 1 & 0 \\
$\begin{array}{l}\text { T. schlegelii } \\
\text { confirmed }\end{array}$ & $\mathbf{1 0}$ & 0 & 0 & 0 \\
$\begin{array}{l}\text { T. schlegelii } \\
\text { probable }\end{array}$ & $\mathbf{1 4}$ & 0 & 0 & 0 \\
$\begin{array}{l}\text { T. schlegelii } \\
\text { confirmed }\end{array}$ & $\mathbf{1 3}$ & 0 & 0 & 0 \\
$\begin{array}{l}\text { T. schlegelii } \\
\text { probable }\end{array}$ & $\mathbf{2 1}$ & 0 & 0 & 0 \\
\hline
\end{tabular}

${ }^{*}$ Partitioned data with daytime sign included in counts

considerably higher than densities recorded in any other tributaries of Air Hitam Laut River in the past.

As we spent only a single day and night on both the Lalan and Simpang Kanan Rivers, we suggest those areas be targeted for future surveys. Although we recorded no crocodilian activity on these rivers, high population densities of T. schlegelii have been reported for the Lalan and Merang Rivers in the past (Bezuijen et al., 1995, 1997, 2001, 2002). Although this study was the first to survey the Simpang Kanan River, its habitat characteristics and proximity to the Lower Kampar River suggest it may be an important river for both C. porosus and T. schlegelii populations, and other neighbouring rivers and sections of mangrove forest may also be important areas for future survey efforts (Shaney et al., 2016).

Our models identified a maximum of $22,396.07 \mathrm{~km}^{2}$ of remaining suitable habitat and a minimum of $3,772 \mathrm{~km}^{2}$ within remaining primary forest areas across the range of T. schlegelii $\left(10,558 \mathrm{~km}^{2}\right.$ suitable habitat remain in Sumatra, $1,548.98 \mathrm{~km}^{2}$ within primary forest). Although T. schlegelii has been found in disturbed habitat previously (Bezuijen et al., 2001; Stuebing et al., 2006), we found the species only in primary forest habitat (Table 4). Therefore, we believe our maximum model estimates could be an overestimation of remaining suitable habitat in the Greater Sunda region (particularly in Sumatra). Furthermore, our quantification included all modelled habitat with probability of occurrence $>0.2 \%$, which is a conservative estimate. Regardless, based on severely fragmented populations, low local population density, when present, and severe habitat fragmentation, we believe that $T$. schlegelii may be locally 


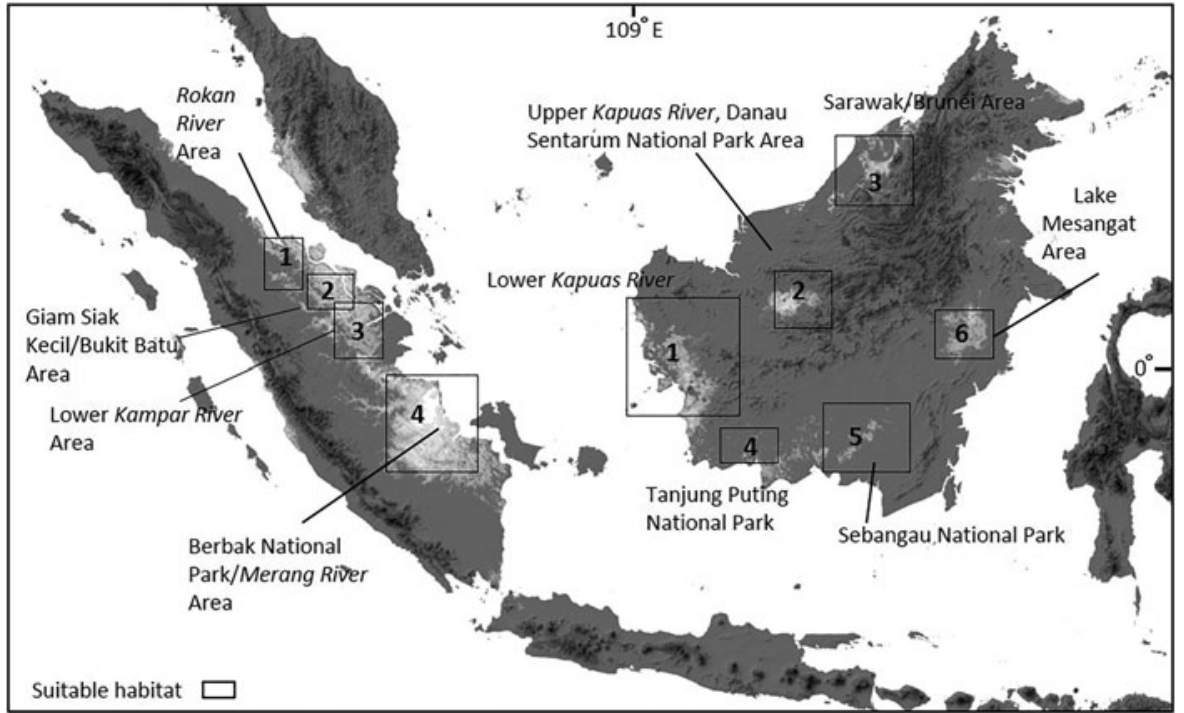

FIG. 2 Suitable habitat for Tomistoma schlegelii in the Greater Sunda region is modelled in white (Model 4). Numbers signify the distinct areas that were found to have suitable habitat for T. schlegelii in the model.
Endangered in Sumatra. We cannot yet assess extent and area of occurrence or make a range-wide assessment without continued work on the island of Borneo and we acknowledge that T. schlegelii may inhabit some areas that were not modelled in our analyses. Future species distribution models would benefit from additional data on the movement ecology of T. schlegelii. Whether or not T. schlegelii commonly inhabits other kinds of habitat or is capable of making ocean crossings between freshwater systems requires further investigation. Such studies could also continue to fine tune habitat suitability models. However, our species distribution modelling approach indicated specific areas in Borneo and Sumatra that should be considered for future population surveys, and showed limited remaining suitable habitat across the species' range (Fig. 2).

Rödder et al. (2010) used a similar modelling approach to study T. schlegelii and identified similar key areas for population viability. Our findings suggest that many of those same locations remain important for $T$. schlegelii conservation. Based on our models, key areas that may be important for T. schlegelii populations in Sumatra include the Air Hitam Laut River system in Jambi; the Merang River system in South Sumatra; the Lower Kampar River system and areas surrounding the Simpang Kanan River system, Bukit Batu and Giam Siak Kecil reserves and the Rokan River in Riau. In Borneo, key areas include the lower and upper Kapuas River in West Kalimantan, Tanjung Puting and Sebangua National Parks in Central Kalimantan, Lake Mesangat in East Kalimantan, and the Labi Forest Reserve area along the Brunei-Sarawak border, including the Belait River and other tributaries (Fig. 2). Lake Mesangat is one of the only known locations in Borneo to also hold populations of the Critically Endangered Crocodylus siamensis (Stuebing et al., 2015).

\section{Reserve expansion}

As there is still intact habitat around the Lower Kampar River and Berbak National Park study areas, we suggest expanding reserves to protect the remaining lowland habitat. There are large areas of primary and secondary forest between Berbak and Sembilang National Parks, as well as between several reserves on the north bank of the Lower Kampar River (Fig. 1). We acknowledge that this may be difficult to accomplish. However, if attempts are not made to initiate expansion of protected areas, remaining habitat will be lost to continued habitat alteration across Sumatra's lowlands. Proposals to the Balai Konservasi Sumber Daya Alam and the Indonesian Institute of Sciences are required first steps, and involvement from stakeholders such as the various IUCN specialist groups could aid significantly in this process. Rödder et al. (2010) also suggested other important areas for reserve expansion, particularly in the lowlands of West Kalimantan, which include most of the areas highlighted in our modelling results. Given the rapid and ongoing forest conversion and degradation across the Greater Sunda region, reserve expansion in suitable habitat for T. schlegelii would also benefit other threatened species, including Sumatran rhinoceroses Dicerorhinus sumatrensis, elephants Elephas maximus, tigers Panthera tigris sumatrae, and clouded leopards Neofelis nebulosa.

Berbak National Park exemplifies the importance of protected areas in Sumatra's lowlands, as evidenced by our survey data. The Park currently protects some of the last lowland swamp forest in Sumatra, as well as some of the island's last remaining populations of Sumatran tigers, false gharials and tapirs Tapirus indicus. The Park has been well managed to date, and if a similar approach were used in protected area expansion there could be a chance to 
protect more of Sumatra's lowland biodiversity. Nonetheless, limited management resources are still a challenge for the Park, and illegal logging activity occurs at its periphery. It is a constant struggle to protect the remaining biodiversity within the Park's boundaries, and continued support from the Indonesian government, NGOs, and the public is critical to the future of the Park.

\section{Acknowledgements}

We are grateful to representatives of the Indonesian Institute of Sciences at the Museum Zoologicum Bogoriense for facilitating the study of crocodiles in Indonesia, as well as field research permits, and to the Ministry of Research and Technology of the Republic of Indonesia for coordinating and granting research permissions. The Forestry Department of Indonesia kindly provided research permits for areas under its jurisdiction. We thank the local communities for their support, advice and kindness during our travels; the members of the field expeditions throughout Sumatra, especially Wayhu Trilaksono; directors and officials at Berbak National Park for their patience and assistance; Agustinus Rante Lembang, Pak Dodi Kurniawan, Pak Erwan, Riziko, Rini, Sismanto, Imron and Rizal Andi Saputra for their help and support; and Pak Kasno, without whom travel during the dry season would not have been possible. We thank Alias, Bagas, Ferry and Muslimin in Berbak National Park, and Khairil, Suandi and Udi in the Lower Kampar River study area; and Bruce Shwedick, Mark Bezuijen, Robert Stuebing and Agata Staniewicz for their advice and assistance. This project was funded by the IUCN Crocodile Specialist Group (Tomistoma Task Force) and National Geographic. Many people at the University of Texas at Arlington contributed significant advice and feedback, including Elijah Wostl, David Sanchez and Utpal Smart.

\section{Author contributions}

KJS obtained research permits, led the field work, conducted analyses and contributed to the article. AH assisted with permitting and field work, and contributed to the article. MW assisted with statistical analyses and contributed to the article. EA and AA assisted with field work and contributed to the article. ENS assisted with funding, permitting and reviewing the article.

\section{References}

Auliya, M., Shwedick, B., Sommerlad, R., Brend, S. \& Samedi (2006) A short-term assessment of the conservation status of Tomistoma schlegelii (Crocodylia: Crocodylidae) in Tanjung Puting National Park (Central Kalimantan, Indonesia). A cooperative survey by the Orangutan Foundation (UK) and the Tomistoma Task Force of the IUCN/SSC Crocodile Specialist Group. Https://www. iucncsg.org/365_docs/attachments/protarea/Tomi-9bc5a8d8.pdf [accessed 4 July 2017].

BAYLISS, P. (1987) Survey methods and monitoring within crocodile management programmes. In Wildlife Management: Crocodiles and Alligators (eds G.J.W. Webb, S.C. Manolis \& P.J. Whitehead), pp. 16-163. Surrey Beatty \& Sons Pty Ltd, Chipping Norton, Australia.

Bezuijen, M.R., Cannucciar, P., Manolis, S.C., Samedi, Kadarisman, R. \& Simpson, B.K. (1995) Project Tomistoma. Field Expedition to the Lalan River and its Tributaries, South Sumatra, Indonesia, August-October 1995: Assessment of the Distribution, Abundance, Status and Nesting Biology of the False Gharial (Tomistoma schlegelii). Wildlife Management International Pty Limited, Darwin, Australia.

Bezuijen, M.R., Hartoyo, P., Elliott, M. \& Baker, B.A. (1997) Project Tomistoma. Second Report on the Ecology of the False Gharial (Tomistoma schlegelii) in Sumatera. Wildlife Management International Pty Limited, Darwin, Australia.

Bezuijen, M.R., Shwedick, B., Simpson, B.K., Staniewicz, A. \& Stuebing, R. (2014) Tomistoma schlegelii. In The IUCN Red List of Threatened Species 2014: e.T21981A2780499. Http://dx.doi.org/10. 2305/IUCN.UK.2014-1.RLTS.T21981A2780499.en [accessed 4 July 2017].

Bezuijen, M.R., Webb, G.J.W., Hartoyo, P. \& Samedi (2001) Peat swamp forest and the false gharial Tomistoma schlegelii (Crocodilia, Reptilia) in the Merang River, eastern Sumatra, Indonesia. Oryx., 35, 301-307.

Bezuijen, M.R., Wibowo, P. \& Wirawijaya, H. (2002) Proceedings of the 2002 False Gharial Workshop: Assessment of the Management and Conservation of the Merang River as Habitat for the False Gharial (Tomistoma schlegelii). Wildlife Management International Pty Limited, Darwin, Australia, and Wetlands International-Indonesia Program, Palembang, Indonesia.

Bonke, R., Auliya, M., Brend, S., Sommerlad, R. \& Böhme, W. (2008) Population Ecology of Tomistoma schlegelii (Müller, 1838) in the Tanjung Puting National Park (Central Kalimantan, Indonesia). Progress report for IUCN/SSC-Tomistoma Task Force.

Brien, M., Shwedick, B., McCaskill, L., Ramono, W. \& Webb, G. (2015) Crocodile Conservation, Management and Farming in Indonesia: A Preliminary Review with Recommendations. Summary report of the IUCN-SSC Crocodile Specialist Group review mission to Indonesia (23 August-17 September 2014).

Brodie, J.F., Giordano, A.J., Zipkin, E.F., Bernard, H., Mohd-Azlan, J. \& Ambu, L. (2015) Correlation and persistence of hunting and logging impacts on tropical rainforest mammals. Conservation Biology, 29, 110-121.

Brooks, T.M., Pimm, S.L. \& Collar, N.J. (1997) Deforestation predicts the number of threatened birds in insular Southeast Asia. Conservation Biology, 11, 382-394.

CITES (2017) The CITES Appendices. Http://www.cites.org/eng/app/ index.shtml [accessed 4 July 2017].

CrocBITE (2016) Worldwide Crocodilian Attack Database. Http:// www.crocodile-attack.info/ [accessed 25 December 2015].

Crocodile Specialist Group (1996) Crocodylus porosus. In The IUCN Red List of Threatened Species 1996: e.T5668A11503588. Http:// dx.doi.org/10.2305/IUCN.UK.1996.RLTS.T5668A11503588.en [accessed 4 July 2017].

DIVA-GIS (2015) http://www.diva-gis.org [accessed 6 May 2016]. Elith, J., Phillips, S.J., Hastie, T., Dudík, M., Chee, Y.E. \& Yates, C.J. (2011) A statistical explanation of MaxEnt for ecologists. Diversity and Distributions, 17, 43-57.

Margono, B.A., Turubanova, S., Zhuravleva, I., Potapov, P., Tyukavina, A., B ACCIni, A. et al. (2012) Mapping and monitoring 
deforestation and forest degradation in Sumatra (Indonesia) using Landsat time series data sets from 1990 to 2010. Environmental Research Letters, 7, http://dx.doi.org/10.1088/1748-9326/7/3/034010.

Miettinen, J., Stibig, H.J. \& Achard, F. (2014) Remote sensing of forest degradation in Southeast Asia-aiming for a regional view through 5-30 m satellite data. Global Ecology and Conservation, 2, 24-36.

Phillips, S.J., Dudík, M. \& Schapire, R.E. (2016) Maxent software for modeling species niches and distributions. Http://biodiversityin formatics.amnh.org/open_source/maxent/ [accessed 10 March 2017]

Rödder, D., Engler, J.O., Bonke, R., Weinsheimer, F. \& Pertel, W. (2010) Fading of the last giants: an assessment of habitat availability of the Sunda gharial Tomistoma schlegelii and coverage with protected areas. Aquatic Conservation: Marine and Freshwater Ecosystems, 20, 678-684.

Shaney, K.J., Hamidy, A. \& Smith, E.N. (2016) Status of the False Gharial in Sumatra. IUCN Crocodile Specialist Group Report. IUCN, Gland, Switzerland.

Shaney, K.J., Trilaksono, W., Hamidy, A. \& Smith, E.N. (2015) Preliminary Assessment of False Gharial (Tomistoma schlegelii) Populations in Sumatra. IUCN Crocodile Specialist Group Report (Tomistoma Task Force). Http://www.iucncsg.org/365_docs/ attachments/protarea/02955f7103662bf1710d9281764de798.pdf [accessed 4 July 2017].

Simpson, B.K. (2014) Status Assessment of Tomistoma in Peninsular Malaysia: Peat Swamp Forests of Selangor \& Pahang. IUCN Crocodile Specialist Group, Tomistoma Task Force.

Sodhi, N.S., Koн, L.P., BrooK, B.W. \& NG, P.K.L. (2004) Southeast Asian biodiversity: an impending disaster. Trends in Ecology \& Evolution, 19, 654-66o.
Stoner, D.C., Wolfe, M.L., Rieth, W.R., Bunnell, K.D., Durham, S.L. \& StoneR, L.L. (2013) De facto refugia, ecological traps and the biogeography of anthropogenic cougar mortality in Utah. Diversity and Distributions, 19, 1114-1124.

Stuebing, R.B., Bezuijen, M.R., Auliya, M. \& Voris, H.K. (2006) The current and historic distribution of Tomistoma schlegelii (the false gharial) (Müller, 1838) (Crocodylia, Reptilia). The Raffles Bulletin of Zoology, 54, 181-197.

Stuebing, R., Sommerlad, R. \& Staniewicz, A. (2015) Conservation of the Sunda gharial Tomistoma schlegelii in Lake Mesangat Indonesia. International Zoo Yearbook, 49, 137-149.

Webi, G.J.W., Manolis, S.C. \& Brien, M.L. (2010) Saltwater Crocodile Crocodylus porosus. IUCN Crocodile Specialist Group report. IUCN, Gland, Switzerland.

World Clim (2016) WorldClim - Global Climate Data. Http:// worldclim.com/ [accessed 20 December 2016].

\section{Biographical sketches}

Kyle Shaney is interested in biogeography, conservation biology, spatial ecology and human-wildlife conflict. His work focuses on both game and non-game species, with an overall goal of improving wildlife management and preservation of biodiversity. AMIR HAMIDY and EVY ARIDA are interested in discovering and managing herpetofaunal biodiversity. MA TT WA LSH has expertise in ecology and statistics. AISYA H ARIM B I is focused on improving conservation strategies in Indonesia. E R IC S M I T H has a particular interest in discovering tropical reptile and amphibian diversity and biogeographical patterns. 